\title{
Evaluation of agricultural land resources for irrigation in the cotton growing Yavatmal district, Maharashtra, India
}

\author{
B. P. Bhaskar ${ }^{*}$, Jadish Prasad ${ }^{1}$ and Gopal Tiwari ${ }^{1}$ \\ Nagpur-440033 (Maharashtra), INDIA \\ *Corresponding author. E-mail: bhaskar_phaneendra@yahoo.co.in \\ Received: April 29, 2016; Revised received: September 27, 2016; Accepted: January 10, 2017
}

${ }^{1}$ Division of Soil Resource Studies, ICAR-National Bureau of Soil Survey and Land Use Planning, Amravati road,

\begin{abstract}
The main objective of this study is to evaluate suitability of shrink-swell soils for surface irrigation system based upon a parametric evaluation system in low irrigation potential (7\%) of cotton growing Yavatmal district, Maharashtra, India. The thirty three shrink-swell soil series on basaltic landforms were identified from reconnaissance soil survey on 1:50,000 scale and evaluated for surface irrigation methods using Geographic Information System (GIS). The standard weekwise rainfall data showed that the rainfall is less than $20 \%$ of total precipitation during September and December, the top A horizon reaches to wilting point and needs supplementary protective irrigation to cotton based cropping systems . It was estimated that ten soil mapping units (1.8 Mha and $13.89 \%)$ of shrink-swell soils on moderate slopes ( 5 to $8 \%$ ) were evaluated as suitable for surface methods and calculated the irrigation intervals that vary from $8.61 \pm 1.35$ days for cotton to $8.9 \pm 1.4$ days for wheat and $10 \pm 1.64$ days for sugar cane. The study emphasized the utility of soil resource maps helps to delineate the soils with large PAWC $(>200 \mathrm{~mm})$ with slight yield advantage and will serve as benchmark sites to monitor the interrelationships of soil water dynamics with respect to climate and cotton yields.
\end{abstract}

Keywords: Land suitability evaluation, Parametric method, Soil series, Surface irrigation

\section{INTRODUCTION}

Maharashtra has an area of $307,780 \mathrm{~km}^{2}$, of which $225,000 \mathrm{~km}^{2}$ is cultivable. Twenty per cent of the cultivable area is served by irrigation infrastructure. Today, the irrigated infrastructure covers 4.5 million hectare (Mha), as compared with potentially irrigable area of 12.6 Mha (that includes ground water irrigation potential) (Chivate, 2010). The irrigation developed so far till June, 2005 is 0.874 Mha from state sector schemes and 0.304 Mha from local sector schemes (total 1.178 Mha). Irrigation potential created as a percent of gross sown area is only $19 \%$ for the region as a against $30 \%$ irrigation coverage for drought proofing. The soil resource inventories in Maharashtra have shown that $1.5 \%$ total geographical area (TGA) in command areas of Godavari, Ghod, Purna, Manar, Mula, Pravara, Nira and Krishna river basins was occupied by moderately to strongly saline/sodic soils (Challa et al., 1995). The parameterric system was used to evaluate land suitability for both surface and drip irrigation in the Ben Slimane province, Morocco (Briza et al., 2001 and Bazzani et al., 2002) and in Senegal (Bienvenue et al., 2003). Likewise, parametric system using GIS was used to determine suitable areas for different irrigation methods in arid parts of southern Ankara and reported that drip type of irrigation system is suitable for more than half of the study area due to soil and topographic limitations (Dengiz, 2006), whereas in north Molasani plain in Iran, it was reported that drainage and calcium carbonates are limiting factors for surface and drop methods (Albaji et al., 2008 and 2014). Similar kind of excercises were reported in evaluating Vertisols and vertic intergrades of basaltic terrain in Jayakwadi command area revealed that these soils have fair to poor productivity with severe limitations of sodicity, low permeability and effective rooting depth for irrigation (Bhaskar et al., 2002 \& 2014b) and of sodicity, erosion, drainage, organic carbon and calcium carbonate in Mula command area of Ahmednagar (Kharche et al., 2010). Henceforth, the objective this study is to evaluate and compare the suitability of Vertisols and vertic intergrades for gravity and drop irrigation methods in semiarid and drought prone cotton growing Yavatmal district in Maharashtra where irrigation potential is $6.8 \%$ of total cultivated area .

\section{MATERIALS AND METHODS}

Description of study area: Yavatmal in the eastern (Vidharbha) region of the Maharashtra state lies between $19^{\circ} 26^{\prime}$ to $20^{\circ} 42^{\prime} \mathrm{N}$ Latitude and $77^{\circ} 18^{\prime}$ to $79^{0} 98^{\prime} \mathrm{E}$ Longitude. This district covers $13,582 \mathrm{~km}^{2}$ area $(4.41 \%$ of the state) with a population of 20 , $77,144(2.63 \%$ of the state $)$ and $43 \%$ of rural families 


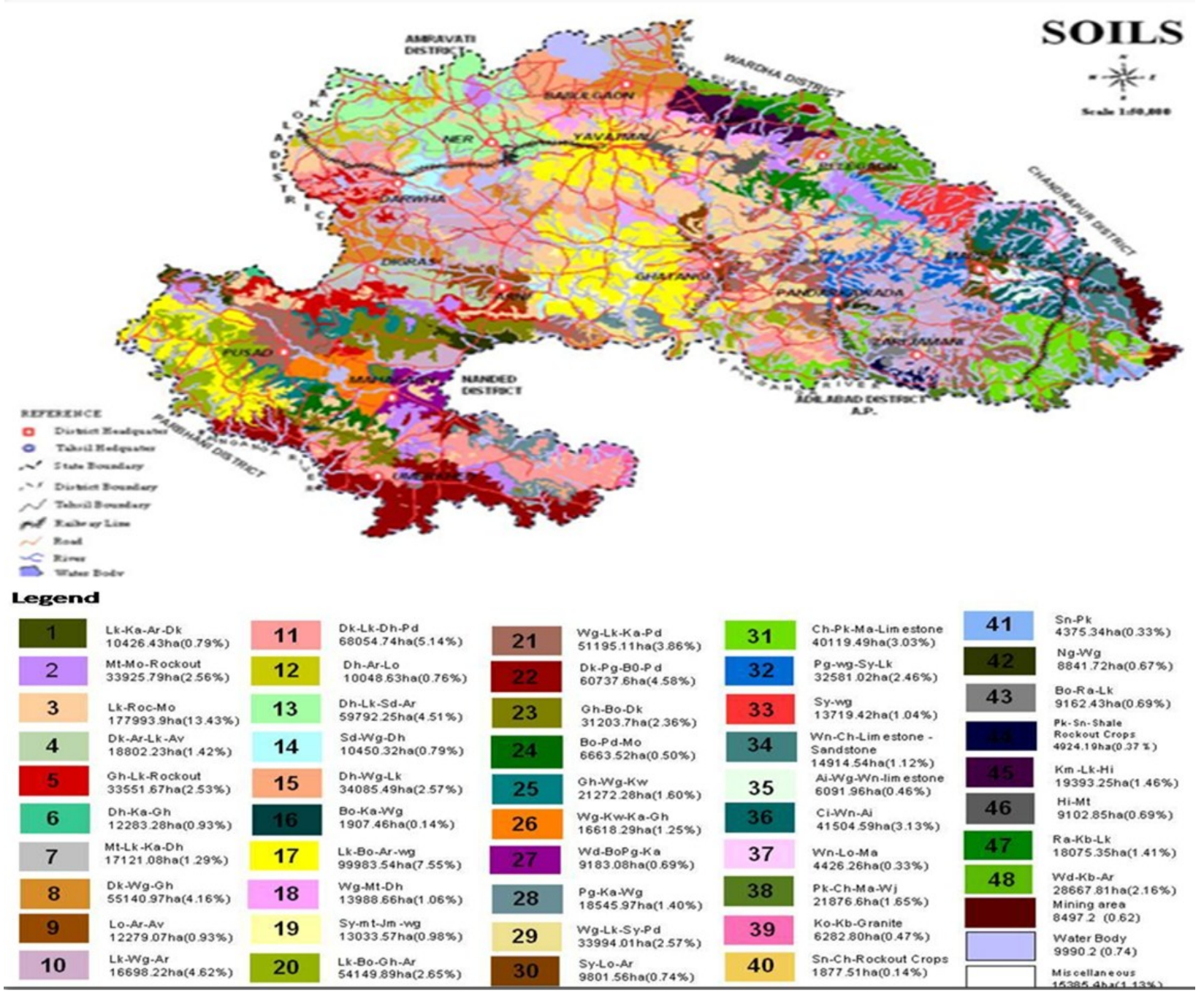

Fig.1. Soil map of Yavatmal district with legend.

live below poverty line. The total cultivated area is 8.84 lakh ha with double cropped area of 41,189 ha with low cropping intensity (101\%) and low irrigation potential (7\%). This district comes under Deccan Plateau, hot semi-arid eco-region of Western Maharashtra plateau and hot moist semi-arid eco-subregion (Mandal et al., 2005). The mean annual rainfall ranges from $1125 \mathrm{~mm}$ in eastern parts of Wani to $962 \mathrm{~mm}$ in western parts of Darwha and $1180 \mathrm{~mm}$ in central portion of Yavatmal showing an increasing trend as one proceeds from West to East. Tehsil wise average rainy days and average rainfall $(\mathrm{mm})$ is recorded as mean rainfall of $1180 \mathrm{~mm}$ with 62 average rainy days in Yavatmal tehsil (Northern side) to minimum of $587 \mathrm{~mm}$ of rainfall in Ner tehsil with 47 rainy days. The major crops are cotton (52\% of total area) followed by Jowar $(22 \%)$ and Redgram $(6.6 \%)$. The water balance diagram of Yavatmal shows that the black soils in the region are saturated with water and kept close to field capacity due to the 70 to $80 \%$ of monsoon rainfall concentrated from June to August. The standard weekwise rainfall data shows that the average amount of weekly rainfall is varied from $52.04 \mathrm{~mm}$ in $24^{\text {th }}$ week to 65.89 $\mathrm{mm}$ at $35^{\text {th }}$ week with variation of $76.53 \%$ to $93.5 \%$ of corresponding weeks. The mean rainy days are more or equal to 4 during $26^{\text {th }}$ week to $33^{\text {rd }}$ week with less than 50 per cent of variation. As the cotton crop calendar extends upto $45^{\text {th }}$ week, there is reduction in amount of rainfall from $38^{\text {th }}$ week from $32.77 \mathrm{~mm}$ to $1.36 \mathrm{~mm}$ at $43^{\text {rd }}$ week (Bhaskar et al., 2014a). The dry stage is often with at least 15 days of dry spells after September $15^{\text {th }}$ in the region. The rainfall is less than $20 \%$ of total precipitation during September and December which is in coincidence of rapid growth of cotton with flowering and boll development stages. During this period, the top A horizon reaches to wilting point and needs supplementary protective irrigation to cotton.

Land resource data: A Reconnaissance soil survey was carried out using 1:50000 scale toposheets of Survey of India (SOI) and Indian Remote Sensing (IRS)P6 false colour composites satellite $\left(11^{\text {th }}\right.$ April $-10^{\text {th }}$ 


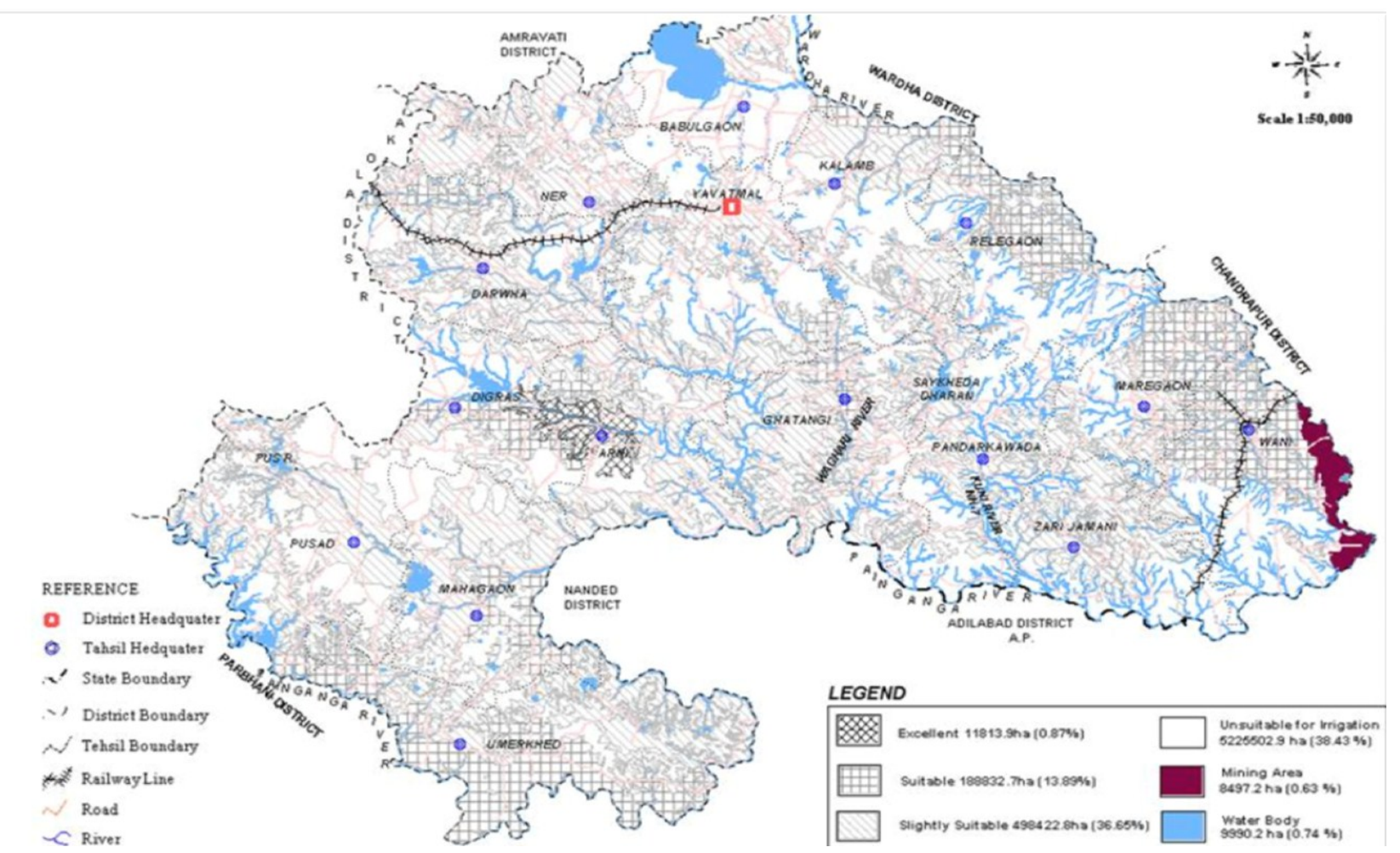

Fig. 2. Agricultural land suitability for surface irrigation.

May, 2006) as base maps for field as per the standard procedures (Martínez Beltrán, 1993). Fourteen landforms were identified such as hills and ridges in northern and central parts of Yavatmal (12.6\% of total area), upper, middle and lower plateaus $(398,240.4$ ha and $29.34 \%$ of total area). Isolated hills/elongated hills mesa and butte, escarpments, upper and lower pediplains (17.74\%) and gently to moderately sloping alluvial plains, very gently sloping to gently sloping plain, intervening valleys in south western parts $(8.05 \%)$ and gullied stony gravelly wastelands (3.4\%). A total of 1450 soil profiles were studied upto a depth of $2 \mathrm{~m}$ or to lithic contact and recorded morphological properties as per Schoeneberger et al. (2002). The soil profiles were classified as per keys to soil taxonomy (Soil Survey Staff, 2014). Thirty three soil series were defined as per the criteria of Reddy (2006). The soil map of Yavatmal district in Geo-media environment was derived with 48 mapping units (Fig. 1).

Laboratory analysis: Horizon wise soil samples were collected and sieved air dry samples through $2 \mathrm{~mm}$ sieve for fine earth fraction. The routine and standard procedures were used for particle size analysis by international pipette method, bulk density by clod method, $\mathrm{pH}$, Electrical conductivity (1:2.5 soil water ratio), organic carbon by wet digestion method, calcium carbonate by acid neutralization method, exchangeable bases with $1 \mathrm{~N}$ ammonium acetate extractable and cation exchange capacity (CEC) with ammonia distillation method (Jackson, 1973) and water retention at $-33 \mathrm{kPa}$ and $-1500 \mathrm{kPa}$ using pressure plate membrane apparatus (Richards, 1954).

Land evaluation for irrigation: The steps followed in land evaluation for irrigation and in deriving thematic map of suitability zones for irrigation were as follows: Step 1.Soil map with limiting symbol formula was used to define limitations of each series in the numerator and topography / drainage in the denominators.

Step 2. Development of capability index and soil units were rated by multiplying the proportion of each soil type by its respective soil rating.

Step.3.Decision rules were proposed for irrigation and derived priority areas suitable for irrigated agriculture using Geo-media.

Parametric evaluation: The parametric evaluation system from Sys et al. (1991 \& 1993) was applied using standard granulometrical and physico-chemical characteristics of a soil profile. The different land characteristics that influence the soil suitability for irrigation are rated and a capability index for irrigation ( $\mathrm{Ci}$ ) is calculated according to the formula:

$\mathrm{Ci}=\mathrm{A} \times \mathrm{B} / 100 \times \mathrm{C} / 100 \times \mathrm{D} / 100 \times \mathrm{E} / 100 \times \mathrm{F} / 100$

Where $\mathrm{A}=$ rating of soil texture, $\mathrm{B}=$ rating of soil depth,C: rating of $\mathrm{CaCO}_{3}$ status,

$\mathrm{D}$ :salinity/alkalinity rating,E: drainage rating and $\mathrm{F}$ : slope rating.

The suitability of shrink - swell soils for irrigation were done by considering soil texture (weighted average to adepth of $100 \mathrm{~cm}$ ), soil depth(thickness and horizon sequences), calcium carbonate content (upto 
$150 \mathrm{~cm})$, salinity, drainage and slope $(\%)$. The rating scheme for suitability for irrigation is presented in table 1 .

Rating soil mapping units: Soil units mapped as complexes were rated by multiplying the proportion of each soil type. The sum of total area of each soil series in the unit to get respective final soil rating (AAFRD, 2004). For example: Soil mapping unit Lo-Ar-Av.

\begin{tabular}{lll}
\hline $\begin{array}{l}\text { Proportion of unit } \\
(\%)\end{array}$ & $\begin{array}{l}\text { Capability } \\
\text { index }\end{array}$ & $\begin{array}{l}\text { Partial soil } \\
\text { rating }\end{array}$ \\
\hline 35 (Loni series ) & 90 & 3150 \\
35 (Arni series) & 73 & 2555 \\
30 (Arunavati series) & 81 & 2430 \\
Final soil rating & & 8135 \\
\hline
\end{tabular}

The capability classes are defined according to the value of the capability (or suitability) index (Ci).

\begin{tabular}{llll}
\hline $\begin{array}{l}\text { Capability } \\
\text { index }\end{array}$ & Class & Definition & Symbol \\
\hline$>80$ & 1 & Excellent & S1 \\
$60-80$ & II & Suitable & S2 \\
$45-60$ & III & Slightly suitable & S3 \\
$30-45$ & IV & Almost unsuitable & N1 \\
$<30$ & V & Unsuitable & N2 \\
\hline
\end{tabular}

Available depth of soil water: Available depth of water is calculated as per the formulae of Gardner et al. (1984)

$$
\mathrm{d}=\frac{F c-P W P}{100} \cdot B D . D
$$

Where $\mathrm{FC}=$ field capacity (Water held at $-33 \mathrm{kPa}$ ), PWP $=$ permanent wilting point (water held at -1500 $\mathrm{kPa}), \mathrm{BD}=$ bulk density $\left(\mathrm{Mg} \mathrm{m}^{-}{ }^{3}\right), \mathrm{D}=$ thickness of horizons.

For each series, these values were calculated, multiplied with proportion of series in each soil mapping unit and summation of series association was considered as final value for each mapping unit. These values were used for computing Irrigation interval as

\section{Allowable soil water depletion \\ Daily water use}

The allowable soil water depletion was $50 \%$ for wheat and cotton and $65 \%$ for sugarcane and daily water use was $0.6 \mathrm{mmday}^{-1}$ for wheat, $0.75 \mathrm{mmday}^{-1}$ for cotton and 0.95 mmday $^{-1}$ for sugar cane (Mohan and Arumugam, 1994).

\section{RESULTS AND DISCUSSION}

Brief description of soil series: The important morphological characteristics of these basaltic soils shows that the occurrence of well drained, dark grey and clay textured he shallow Lakhi and very shallow Gahuli series on hills and ridges (Table 2). These soils are associated with moderately deep Hirdi series having dark brown matrix, with distinct slickensides within $1 \mathrm{~m}$ on upper plateaus and mildly alkaline shallow Jamwadi, strongly alkaline very deep Kalmab and moderately deep Katherwadi series on middle plateaus and moderately alkaline Koulambi series on lower plateaus. The Korta and Ralegaon soil series on isolated hills have dark brown to black subsurface layers (7.5 hue to 10YR hue) clay textured, moderately alkaline with prominent slickensided zones whereas mesas, butte and steep escarpments have very shallow, well drained Moho series and moderately deep Waghari series with dark grey, moderately alkaline, clay subsoils and cambic horizons. The upper and lower pediplains have dark greyish brown to dark brown matrix with slickensided zone within $1 \mathrm{~m}$ in Apti and Saykheda series whereas alluvial plains of Penganga and Pus valleys have deep, moderately alkaline and calcium carbonate enriched slickensided zone in Arunavati, Chanoda, Loni, Pandhurna and Wani soil series. The gullied and stony gravelly waste unit has shallow to very shallow Moregaon, Pandharkawada and Wanjari series having dark yellowish brown (Wanjari) to brown (Pandharkawada) and very dark greyish brown (Moregaon) with mildly to moderately alkaline and clay textured cambic horizons.

Physical and chemical characteristics: The particle distribution data shows that Nagdhari (P22) and Waghari (P30) soils have clay less than $35 \%$ in soil control section $(25-100 \mathrm{~cm})$ with fine loamy particle size whereas Loni (P17) and Saykheda (P27) series have fine silty particle size with silt content exceeding 40\% (Table 3). The Apti (P3), Chanoda (P6), Dhanki (P8), Hirdi (P10), Lakhi (P18) and Penganga series (P25) have very fine particle size with clay more than $60 \%$ (Soil Survey Staff, 2014) but in other soils, the particle size is fine. These expansive clay soils have bulk density of 1.57 to $1.79 \mathrm{Mg} \mathrm{m}^{-3}$ causing root hindrance and aeration (Geus, 1973) and COLE value of 0.1 to 0.2 indicating very severe shrink swell hazard (Schafer et al, 1976). The high COLE values in these soils indicate dominance of montmorillonite controlling the degree of shrinkage. These soils have mean plant available water of $12.65 \%$ with $2.95 \%$ of standard deviation. The plant available water can be approximated with multiple regression equation with $\mathrm{R}^{2}$ value of 0.294 , and $F$ value of 2.25 .

Plant available water $(\%)=-6.39+0.156$ (sand) + 0.283 (silt \%) +0.189 (clay \%) -0.433 (organic carbon, $\left.\mathrm{g} \mathrm{kg}^{-1}\right)-0.022$ (calcium carbonate, $\mathrm{g} \mathrm{kg}^{-1}$ ).

These soils are moderately to strongly alkaline with low salt concentration (Table 3). Sixty seven per cent of soils are low in organic carbon (less than 0.5) and remaining $33 \%$ soils are medium $(0.5$ to $0.75 \%)$. The calcium carbonate content less than $1 \%$ is observed in Dhanki series (P8) whereas as less than $6 \%$ in case of Chanoda (P6), Jamwadi (P11), Koulambi (P13), Katherwadi (P14), Korta (P15), Kharbi (P16), Loni 
B. P. Bhaskar et al. / J. Appl. \& Nat. Sci. 9 (1): 102 - 113 (2017)

Table 1. Rating scheme for evaluating suitability of soils for surface irrigation.

(a) Rating of textural classes for surface and drip irrigation

\begin{tabular}{|c|c|c|c|c|c|c|c|c|c|c|}
\hline \multirow{3}{*}{$\begin{array}{l}\text { Textural } \\
\text { classes }\end{array}$} & \multicolumn{5}{|c|}{ Rating for surface irrigation } & \multicolumn{5}{|c|}{ Rating for drip irrigation } \\
\hline & \multicolumn{3}{|c|}{$\begin{array}{c}\text { Fine gravel } \\
(\%)\end{array}$} & \multicolumn{2}{|c|}{$\begin{array}{c}\text { Coarse gravel } \\
(\%)\end{array}$} & \multicolumn{3}{|c|}{ Fine gravel (\%) } & \multicolumn{2}{|c|}{$\begin{array}{c}\text { Coarse gravel } \\
(\%)\end{array}$} \\
\hline & $<15$ & $15-40$ & $40-75$ & $15-40$ & $40-75$ & $<15$ & $15-40$ & $40-75$ & $\overline{15-40}$ & $40-75$ \\
\hline $\mathrm{CL}^{\square} \square$ & 100 & 90 & 80 & 80 & 50 & 100 & 90 & 80 & 80 & 50 \\
\hline $\mathrm{SiL}$ & 100 & 90 & 80 & 80 & 50 & 100 & 90 & 80 & 80 & 50 \\
\hline SCL & 95 & 85 & 75 & 75 & 45 & 95 & 85 & 75 & 75 & 45 \\
\hline $\mathrm{L}$ & 90 & 80 & 70 & 70 & 45 & 90 & 80 & 70 & 70 & 45 \\
\hline $\mathrm{SiL}$ & 90 & 80 & 70 & 70 & 45 & 90 & 80 & 70 & 70 & 45 \\
\hline $\mathrm{Si}$ & 90 & 80 & 70 & 70 & 45 & 90 & 80 & 70 & 70 & 45 \\
\hline $\mathrm{SiC}$ & 85 & 95 & 80 & 80 & 40 & 85 & 95 & 80 & 80 & 40 \\
\hline $\mathrm{C}$ & 85 & 95 & 80 & 80 & 40 & 85 & 95 & 80 & 80 & 40 \\
\hline $\mathrm{SC}$ & 80 & 90 & 75 & 75 & 35 & 95 & 90 & 85 & 80 & 35 \\
\hline SL & 75 & 65 & 60 & 60 & 35 & 95 & 85 & 80 & 75 & 35 \\
\hline LS & 55 & 50 & 45 & 45 & 25 & 85 & 75 & 55 & 60 & 35 \\
\hline S & 30 & 25 & 25 & 25 & 25 & 70 & 65 & 50 & 35 & 35 \\
\hline
\end{tabular}

CL: Clay Loam SiL: Silty Loam SCL: Sandy Clay Loam L: Loam SiL: Silty Loam Si: Silty, SiC: Silty Clay C: Clay SC: Sandy Clay SL: Sandy Loam LS: Loamy Sand S: Sandy.

(b) Rating for soil depth, $\mathrm{CaCO}_{3}$ and salinity classes for surface and drip irrigation systems

\begin{tabular}{|c|c|c|c|c|c|c|c|c|c|c|}
\hline \multirow[b]{2}{*}{$\begin{array}{l}\text { Soil depth } \\
\text { (cm) }\end{array}$} & \multirow{2}{*}{ Surface } & \multirow{2}{*}{ Drip } & \multirow[b]{2}{*}{$\begin{array}{l}\mathrm{CaCO}_{3} \\
(\%)\end{array}$} & \multirow[b]{2}{*}{$\begin{array}{l}\text { Sur- } \\
\text { face }\end{array}$} & \multirow{2}{*}{ Drip } & \multirow[b]{2}{*}{$\begin{array}{l}\text { Salinity } \\
\operatorname{Ec}\left(\mathrm{dSm}^{-1}\right)\end{array}$} & \multicolumn{2}{|c|}{ Surface } & \multicolumn{2}{|c|}{ Drip } \\
\hline & & & & & & & $\begin{array}{c}\mathrm{C}, \mathrm{SiC}, \\
\mathrm{SiCL}, \mathrm{S}, \mathrm{SC}\end{array}$ & $\begin{array}{c}\text { Other } \\
\text { textures }\end{array}$ & $\begin{array}{c}\mathrm{C}, \mathrm{SiC}, \\
\mathrm{SiCL}, \mathrm{S}, \mathrm{SC}\end{array}$ & $\begin{array}{c}\text { Other } \\
\text { textures }\end{array}$ \\
\hline$<20$ & 25 & 35 & $<0.3$ & 90 & 90 & $<4$ & 100 & 100 & 100 & 100 \\
\hline $20-50$ & 60 & 70 & $0.3-10$ & 95 & 95 & $4-8$ & 90 & 95 & 95 & 95 \\
\hline $50-80$ & 80 & 90 & $10-25$ & 100 & 95 & $8-16$ & 80 & 50 & 85 & 50 \\
\hline $80-100$ & 90 & 100 & $25-50$ & 90 & 80 & $16-30$ & 70 & 30 & 75 & 35 \\
\hline$>100$ & 100 & 100 & $>50$ & 80 & 70 & $>30$ & 60 & 20 & 65 & 25 \\
\hline
\end{tabular}

(c) Rating of drainage classes for surface and drip irrigation

\begin{tabular}{|c|c|c|c|c|}
\hline \multirow[b]{2}{*}{ Drainage classes } & \multicolumn{2}{|c|}{ Rating for surface irrigation } & \multicolumn{2}{|c|}{ Rating for drip irrigation } \\
\hline & C, SiC, SiCL, S, SC Textures & Other textures & $\overline{\mathrm{C}, \mathrm{SiC}, \mathrm{SiCL}, \mathrm{S}, \mathrm{SC} \text { textures }}$ & Other textures \\
\hline Well drained & 100 & 100 & 100 & 100 \\
\hline Moderately drained & 80 & 90 & 100 & 100 \\
\hline Imperfectly drained & 70 & 80 & 80 & 90 \\
\hline Poorly drained & 60 & 65 & 70 & 80 \\
\hline Very poorly drained & 40 & 65 & 50 & 65 \\
\hline Drainage status not known & 70 & 80 & 70 & 80 \\
\hline
\end{tabular}

(d) Rating of slope for irrigation.

\begin{tabular}{|c|c|c|c|c|}
\hline \multirow[b]{2}{*}{ Slope Classes (\%) } & \multicolumn{2}{|c|}{ Rating for surface irrigation } & \multicolumn{2}{|c|}{ Rating for drip irrigatio } \\
\hline & Non-terraced & Terraced & Non-terraced & terraced \\
\hline $0-1$ & 100 & 100 & 100 & 100 \\
\hline $1-3$ & 95 & 95 & 100 & 100 \\
\hline $3-5$ & 90 & 95 & 100 & 100 \\
\hline $5-8$ & 80 & 90 & 90 & 100 \\
\hline $8-16$ & 70 & 80 & 80 & 90 \\
\hline $16-30$ & 50 & 65 & 60 & 75 \\
\hline$>30$ & 30 & 45 & 40 & 55 \\
\hline
\end{tabular}


B. P. Bhaskar et al. / J. Appl. \& Nat. Sci. 9 (1): 102 - 113 (2017)

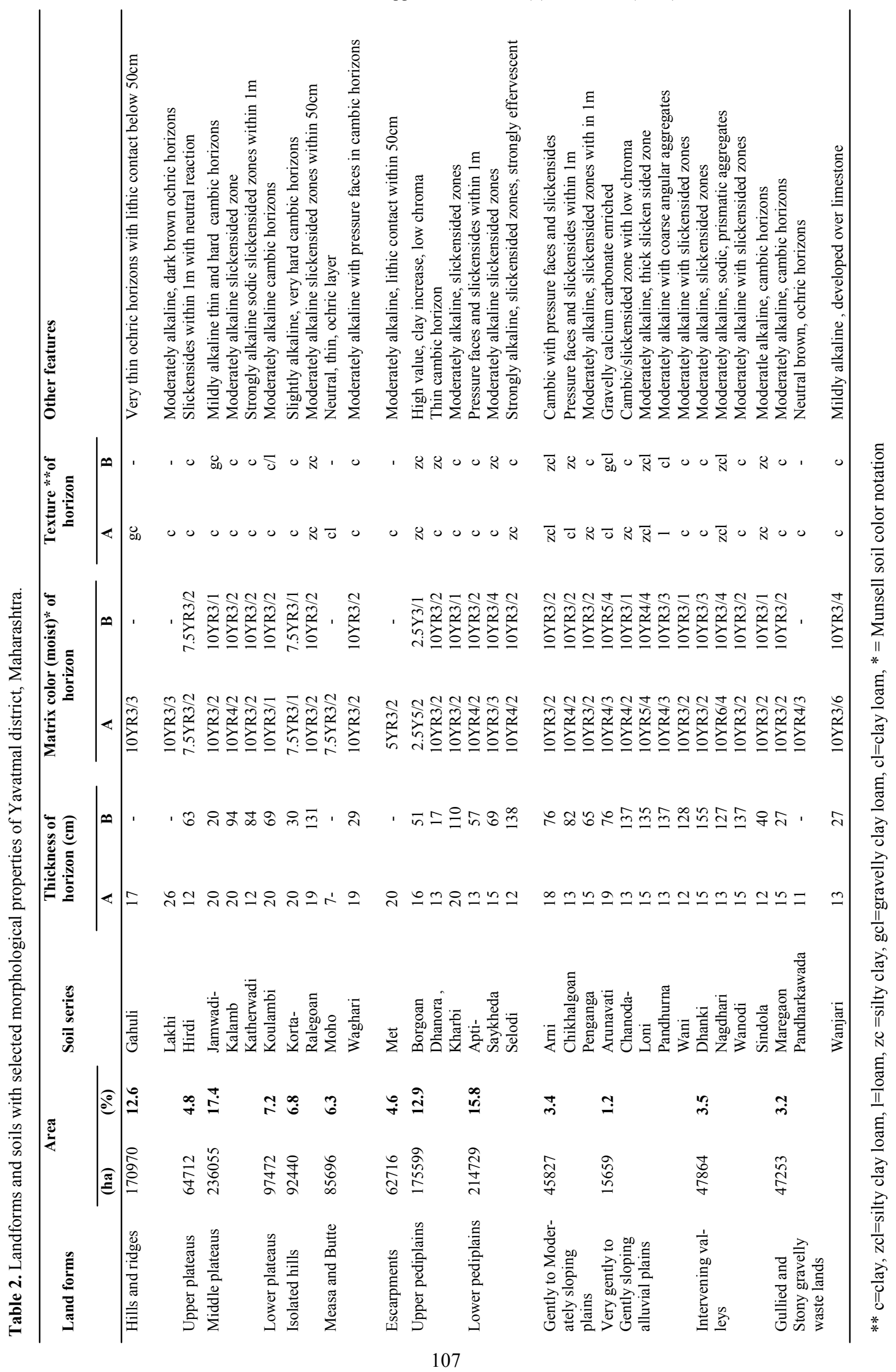


B. P. Bhaskar et al. / J. Appl. \& Nat. Sci. 9 (1): 102 - 113 (2017)

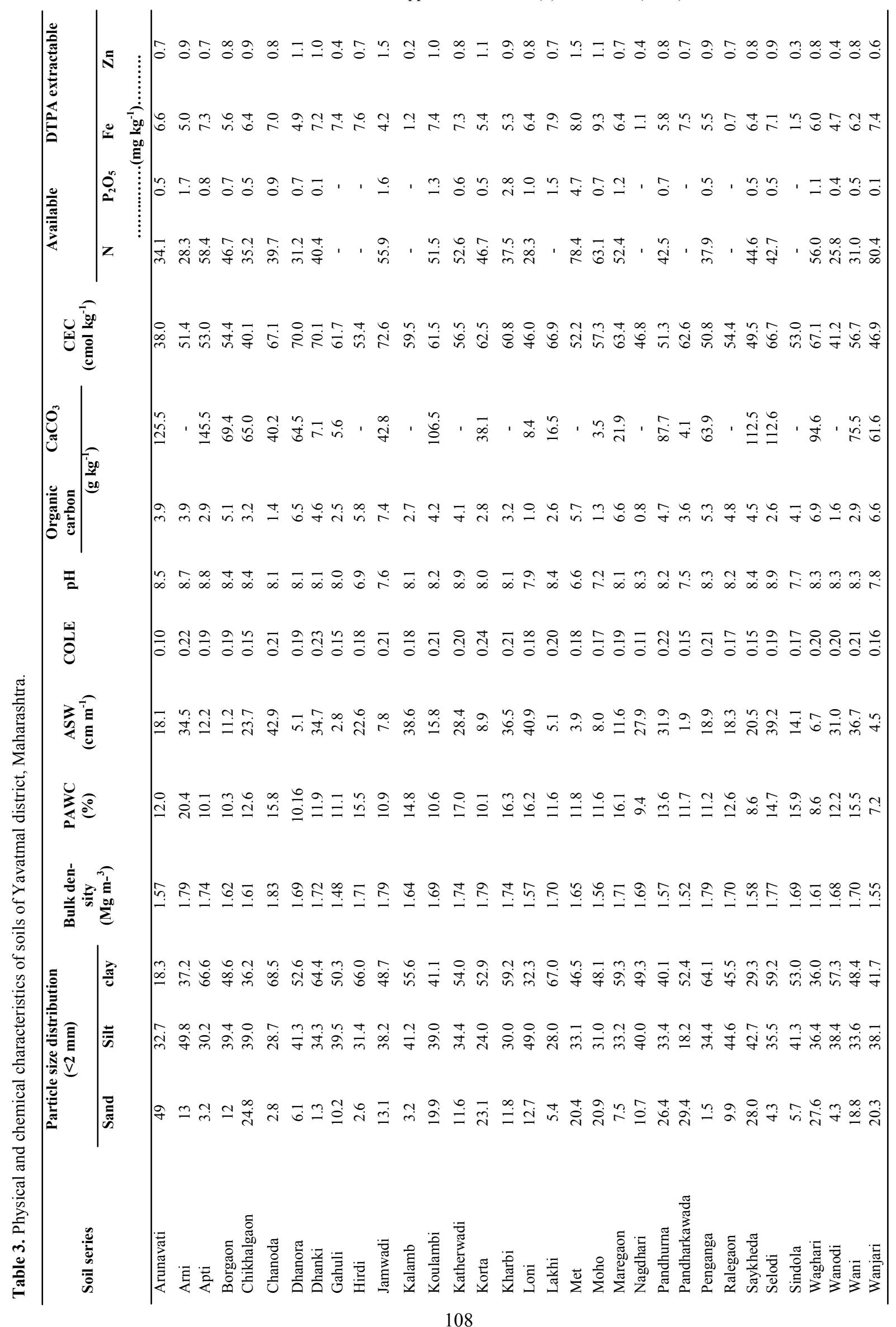


B. P. Bhaskar et al. / J. Appl. \& Nat. Sci. 9 (1): 102 - 113 (2017)

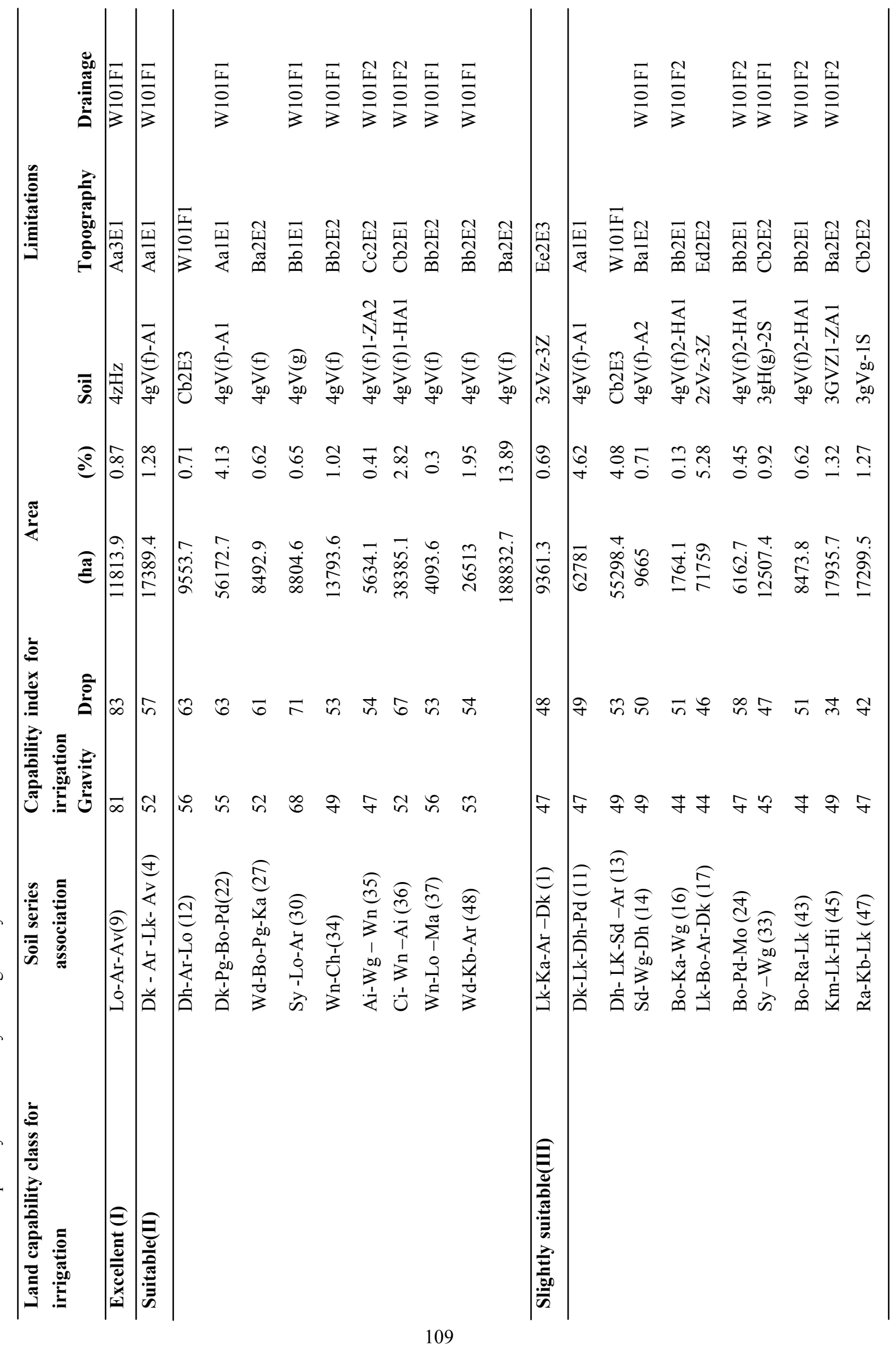


B. P. Bhaskar et al. / J. Appl. \& Nat. Sci. 9 (1): 102 - 113 (2017)

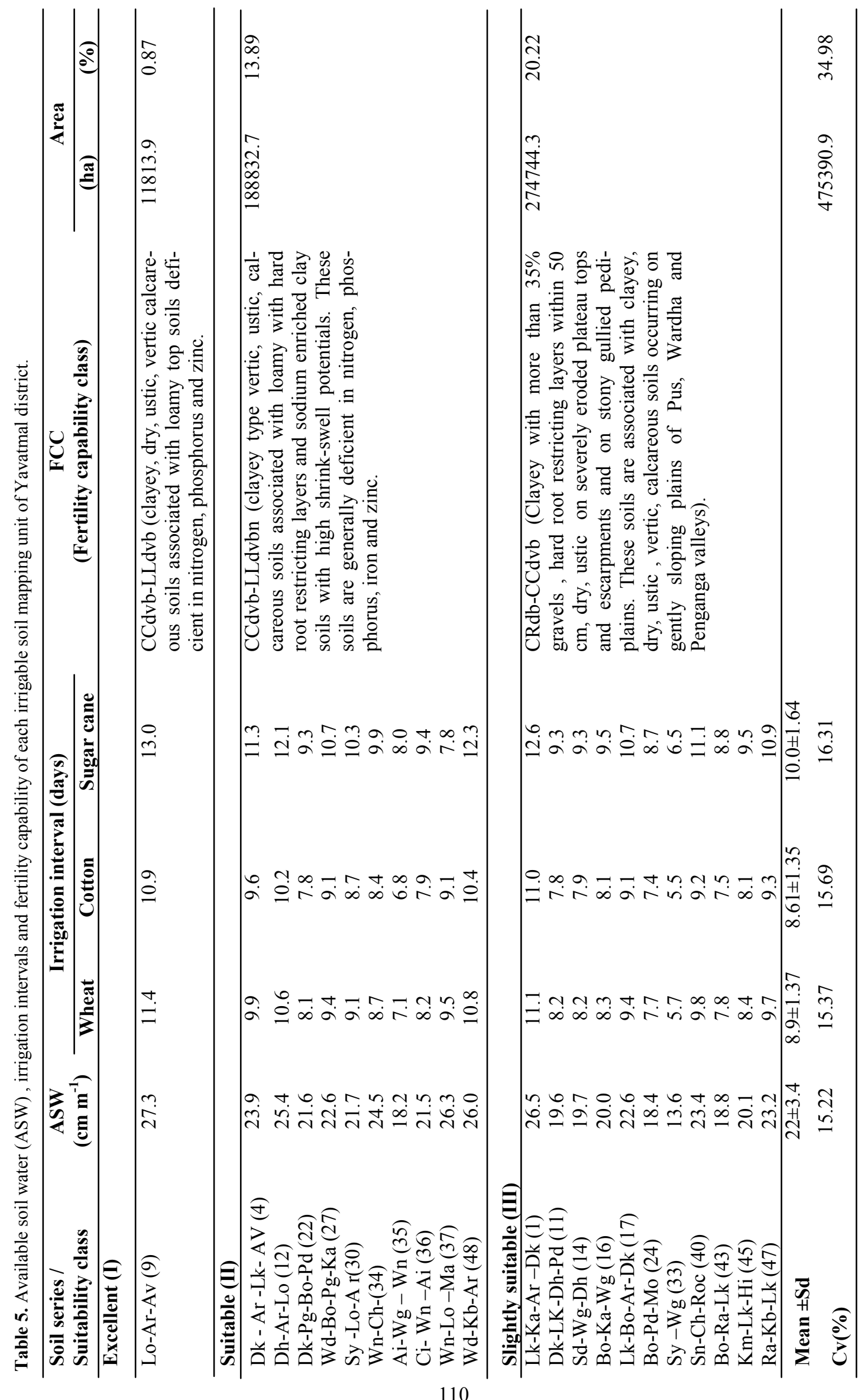


(P17), Moho (P20), Nagdhari (P22), Penganga (P25), Ralegaon (P26), Sindola (P29) and other soils, the $\mathrm{CaCO}_{3}$ content is in between 5 to $10 \%$. The weighted mean of calcium carbonate is $125.48 \mathrm{~g} \mathrm{~kg}^{-1}$ for Arunavati (P1), $122.4 \mathrm{~g} \mathrm{~kg}^{-1}$ for Saykheda (P27), 94.6 $\mathrm{g} \mathrm{kg}^{-1}$ for Waghari (P30) and $75.46 \mathrm{~g} \mathrm{~kg}^{-1}$ for Wani (P32).

These soils are deficient in available nitrogen with mean of $33.17 \mathrm{mg} \mathrm{kg}^{-1}$ and phosphorus with mean of $0.74 \mathrm{mg} \mathrm{kg}^{-1}$ (Table 3). This observation is in agreement with the earlier reports of fertility status of black soils in India (Rao et al., 1997). The DTPA extractable iron shows below critical limit $<4 \mathrm{mg} \mathrm{kg}^{-1}$ in Kalamb (P12), Nagdhari (P22), Pandhurna (23), Ralegaon (P26) and Sindola soils (P29) where as in other soils, DTPA extractable iron is medium (4 to $6 \mathrm{mg} \mathrm{kg}^{-1}$ ). The DTPA extractable $\mathrm{Zn}$ is $0.2 \mathrm{mg} \mathrm{kg}^{-1}$ (P12) to $1.5 \mathrm{mg} \mathrm{kg}$ ${ }^{-1}$ (P11). The $\mathrm{Zn}$ contents below critical limit $(<1 \mathrm{mg}$ $\mathrm{kg}^{-1}$ ) is recorded in Gahuli (P9), Kalamb (P12), Nagdhari (P22), Ralegaon (P26), Sindola (P29) and Wanodi (P31) but in other soils, zinc was medium (Benton Jones, 2001).

Land capability and suitability for irrigation: The limiting factors that lower suitability of basaltic clay soils for irrigation in the study area are mainly the slope, depth of soil, alkalinity, drainage and $\mathrm{CaCO}_{3}$ content. The land capability index (LCI) is computed for judging the suitability for irrigation (Table 4) and defined soil-topography - drainage limitations with standard symbols for irrigable soil mapping unit in Yavatmal district. The excellent soil for irrigation covers $0.87 \%$ with soil associations of Loni series (LCI of 90), Arni series (LCI of 73) and Arunavati series (LCI of 81). These soils have moderate to slow subsoil permeability, medium to heavy top soil texture, deep with unweathered hard rock / calcareous material with slight alkalinity problem, moderate to strong microrelief variations and moderate erosion status. This unit is evaluated as suitable for surface irrigation systems. The excellent soils for irrigation are mostly concentrated in Digras and Arni tehsils of Pus valley under Arunavati river (Fig. 2).

Ten soil mapping units $(4,12,22,27,30,34,35,36$, 37 and 48 ) are evaluated as suitable for irrigation covering $188,832.7$ ha $(13.89 \%)$. These units have 12 series associations viz., Arni, Apti, Chikalgaon, Chanoda, Dhanki, Kalam, Kolambi, Kharbi, Nagdhari, Pandhurna, Wanodi and Wani with moderate to slow subsoil permeability, 15 to $40 \%$ subsoil stoniness, heavy to very heavy top soil texture, deep with unweathered hard rock / calcareous material with slight salinity and alkalinity problem over gently sloping to sloping transversal slopes of 5 to $8 \%$ and slight to moderate water erosion status. The morphological homogeneity in shrink-swell features of these soil mapping units except slope that trigger the application rate of irrigation water and causes nutrients, soil and water loss by runoff process. These results are in agreement with the findings of Mohammad et al. (2010). The slightly suitable soils for irrigation include 11 soil mapping units for irrigation covering $20.22 \%$ of area $(274,744.3 \mathrm{ha})$. These units have dominant soil associations of Borgaon, Dhanora, Katherwadi, Penganga, Ralegaon, Saykheda and Selodi having moderate to slow subsoil permeability and severe stoniness over 5 to $8 \%$ slopes with moderate to severe erosion.

Available soil water, irrigation intervals and fertility capability for irrigable units: The mean available soil water content of 22 soil units is $22 \pm 3.4 \mathrm{~cm} \mathrm{~m}^{-1}$ with coefficient of variation of $15.22 \%$ (Table 5). For these soil units, the irrigation intervals vary from 8.61 \pm 1.35 days for cotton to $8.9 \pm 1.4$ days for wheat and $10 \pm 1.64$ days for sugar cane. The area under excellent units is estimated as $0.87 \%$ with $13.89 \%$ of suitable and $20.22 \%$ under slightly suitable units for irrigation. The excellent mapping unit (Lo-Ar-Av) have available soil water of $27.3 \mathrm{~cm} \mathrm{~m}^{-1}$ whereas 10 suitable mapping units have mean of $23.17 \mathrm{~cm} \mathrm{~m}^{-1} \pm 2.53 \mathrm{~cm} \mathrm{~m}^{-1}$ and in 11 slightly suitable units have mean of $20.53 \pm 3.36$ $\mathrm{cm} \mathrm{m} \mathrm{m}^{-1}$. The crop coefficient $(\mathrm{kc})$ of cotton with growth cycle of 190 days to be $0.46,0.70,1.01$ and 0.39 at four different stages (Mohan and Arumugam 1994). are used to compute mean irrigation intervals which is varying from 8.8 days for cotton to 9.1 days for wheat and 10.11 days for sugarcane in case of suitable units but 8.2 days for cotton to 9.71 days for sugarcane in slightly suitable units. These computed values for irrigation intervals are in agreement with the earlier findings of shrink-swell soils in Jayakwadi irrigation project (Bhaskar et al., 2002). It was reported that cotton field was sampled on each of 2, 5 and 10 days after an irrigation. It was observed that air-filled porosity was $<10 \%$ below $20 \mathrm{~cm}$ after five days of irrigation whereas it did not attain value less than $10 \%$ of air filled porosity at a depth of $40 \mathrm{~cm}$ even after 10days (McGarry and Chan, 1984). They reported that the vertisols must have $10 \%$ air-filled pores as a critical value for plant root respiration beneath $20 \mathrm{~cm}$ after 5 days of irrigation and to $40 \mathrm{~cm}$ for 10 days.

The fertility capability classification (Sanchez et al., 2003). shows that calcareous loamy top vertic soil association in excellent units are deficient in nitrogen, phosphorus and zinc where as hard root restricting and sodium enriched sub soils in case of suitable and of stony to gravelly root restricting vertic soil associations on gullied escarpments and clayey, calcareous soils in Pus and Wardha valleys under slightly suitable units (Table 5). The moderately deep clays have few limitations but shallow soils are unsuitable for all forms of irrigated cropping due to several limitations including wetness, soil depth, rockiness and water erosion hazard. The importance of climate for cotton based systems in Maharashtra is critically analyzed 
and reported that the rainfall of 250 to $325 \mathrm{~mm}$ from squaring to peak flowering stage was found to be critical (Mandal et al., 2005). Hence the climate of Yavatmal for cotton is moderately suitable with short dry spells at critical stages of cotton during September to October. This region experiences 12 to 20 normal dry weeks followed by 3 to 8 weeks of wet weeks from 35 years of daily rainfall data using standard precipitation index (Bhaskar et al., 2011 \& 2014b). The success of rainfed cotton needs better understanding of the effects of plant available water (PAWC), amount and variability of seasonal rains and mean crop yield analysis over basaltic landscapes in the region. The cotton cropping strategies in the region where $14 \%$ of area is suitable for irrigation needs to address the relational data sets of PAWC -climate - yield analysis under rainfed conditions so as to record the probability of achieving high yields and chance of avoiding monetory losses due to prolonged dry spells during cropping period. The soil resource maps helps to delineate the soils with large PAWC ( $>200 \mathrm{~mm})$ with slight yield advantage during dry periods because these soils never attain to maximum soil water storage capacity. The delineated soil mapping units will serve as benchmark sites to monitor the interrelationships of soil water dynamics with respect to climate and cotton yields.

\section{Conclusion}

The soil resource evaluation for irrigation in debt driven and drought prone cotton growing Yavamal district showed that the suitable land for irrigation is only $15 \%$ of total cultivated area. The parametric evaluation further showed $13.89 \%$ of irrigable area on moderate slopes (5 to $8 \%$ ) are evaluated as suitable for surface methods whereas $20.22 \%$ of irrigable land is slightly suitable for drop irrigation with limitations of moderate to slow subsoil permeability, severe stoniness over 5 to $8 \%$ slopes and moderate to severe erosion. The irrigation frequencies of irrigable mapping units varied from 8.8 days for cotton to 9.1 days for wheat and 10.11 days for sugarcane. The study would be helpful in designing crop calendar under irrigated tract as per soil water retention characteristics and water availability and to identify the suitable zones for diversified cropping systems that is economically benefit to the farmers of Vidharbha region.

\section{ACKNOWLEDGEMENTS}

Authors wish to express their sincere thanks to Dr. C. Mandal and her staff in helping GIS analysis in her Lab. Authors expresses their sincere thanks to the Head, Agricultural Research Station, Department of Agriculture, Yavatmal and District Economics and Statistics for providing rainfall and cropping data useful for interpretation of soil resource data.

\section{REFERENCES}

AAFRD (2004). Procedures Manual for Land Classification for Irrigation in Alberta. Alberta Agriculture, Food and Rural Development. Resource Management and Irrigation Division Irrigation Branch, Lethbridge, Alberta.pp.1-83

Albaji, M., Golabi, M., Piroozfar, V.R., Egdernejad, A. and Nazari Zadeh, F. (2014). Evaluation of Agricultural Land Resources for Irrigation in the Ramhormoz Plain by using GIS. Agriculturae Conspectus Scientifics, 79 (2), 93-102

Bazzani, F., Incerti, F. (2002). Land Evaluation in the Province of Larache, Morocco. 22 $2^{\text {nd }}$ Course Professional Master. Geometric and Natural Resources Evaluation. 12 Nov 2001-21 June 2002. IAO, Florence, Italy. http:// www.iao.florence.it/training/geomatics /Larache/ Morocco 22.pdf

Benton Jones, J. Jr. (2001). Laboratory guide for conducting soil tests and plant analysis. CRC press LLC. Boca Raton, Florida.

Bhaskar, B. P.; Sarkar, Dipak; Bobade, S. V.; Gaikwad, S. S. and Anantwar, S. G. (2014a). Land evaluation for irrigation in cotton growing Yavatmal district, Maharashtra. International Journal of Research of Agricultural Sciences.1(2):128-136

Bhaskar, B.P., Dipak Sarkar, Bobde, S.V., Gaikwad, M.S., Gaikwad, S.S., Nimkar, A.M., Anantwar, S.G., Patil, S.V. and Bhattacharyya, T. (2011). Land evaluation for optimal land use plans in cotton growing Yavatmal district, Maharashtra. Ecoscan, special issue, 1: 251-9

Bhaskar, B.P., Gajbhiye, K.S. and Anantwar, S.G. (2002). Soil-site suitability evaluation for Irrigation in Minor-4 of Jayakwadi Command Area, Parbhani district, Maharashtra. National Seminar on "Droughts and Water resources". IWRS, pp.128-35.

Bhaskar B.P., Dipak Sarkar, Mandal C., Bobade S.V., Gaikwad M.S., Gaikwad S.S. (2014). Reconnaissance soil survey of Yavatmal district, Maharashtra, India. NBSS Publication. No.1059, NBSS\&LUP, Nagpur. pp.208.

Bienvenue, J.S., Ngardeta, M. and Mamadou, K., (2003). Land Evaluation in the Province of Thies, Senegal. $23^{\text {rd }}$ Course Professional Master. Geometric and Natural Resources Evaluation. 8t $\mathrm{t}^{\mathrm{h}}$ Nov, 2002-20 June, 2003. IAO, Florence, Italy. http://www.iao.florence. It/ training/geomatics/Thies/senega 123.pdf.

Briza, Y., Dileonardo, F. and Spisni, A. (2001). Land Evaluation in the Province of Ben Slimane, Morocco. $21^{\text {st }}$ Course Professional Master Remote Sensing and Natural Resource Evaluation. IAO, Florence, Italy. http:// www.iao. Florence .it/training/geomatics/BenSlimane/ Marocco 21.pdf.

Challa, O., Vadivelu, S., and Sehgal, J.L. (1995). Soils of Maharashtra for optimizing land use. NBSS Publication 54b.N.B.S.S.\&L.U.P., Nagpur, India.

Chivate, B. A. (2010). Irrigation Performance Benchmarking in Maharashtra. CRBOM Small Publications Series No. 23, Center for River Basin Organizations and Management, Solo, Central Java, Indonesia.pp.1-9.

Dengiz, O. (2006). Comparison of different Irrigation Methods Based on the Parametric evaluation approach. Turk.J. Agric. For., 30: 21-29.

Gardner, E A, Shaw R J, Smith G D and Coughlan K J. (1984). Plant available water capacity: concept, meas- 
urement and prediction. In: J McGarity, E H Hoult and H B So (eds), Properties and utilization of cracking clay soils. Reviews in Rural Science No. 5. University of New England, Armidale, NSW, Australia. pp.164-175.

Geus, J.G.De. (1973). Fertilizer Guide for Tropics and Subtropics (2nd edition), Centre d'Etude de l'Azote, Zurich, pp 774.

Jackson, M.L. (1973). Soil chemical analysis. Prentice Hall of India. Pvt. Ltd. New Delhi.

Kharche, V.K. and Pharande, A (2010). Land degradation assessment and land evaluation in Mula Command area of Irrigated agroecosystem of Maharashtra. Journal of the Indian Society of Soil Science, 58(2), 221-27

Mandal, D K., Mandal, C. and Venugopalan, M.V. (2005). Suitability of cotton cultivation in shrink swell soils in central India. Agricultural Systems, 84, 55-75

Martínez Beltrán J. (1993). Soil survey and land evaluation for planning, design and management of irrigation districts. Etat de l'Agriculture en Méditerranée. Les sols dans la région méditerranéenne : utilisation, gestion et perspectives d'évolution . Zaragoza : CIHEAM, p. 179194 (Cahiers Options Méditerranéennes; n. 1(2))

McGarry, D. and Chan, K.Y. (1984). Preliminary investigation of clay soils' behaviour under furrow irrigated cotton. Australian Journal of Soil Research, 22: 99-108

Mohammad, A., Saeed Boroom, N., Abd Ali, N. and Siroos, J. (2010). Comparison of Different Irrigation Methods Based on the Parametric method in the Plain West of Shush: Iran. Irrigation and Drainage, 59, 547-58

Mohan, S. and Arumugam, N. (1994) Crop coefficient of major crops in South India. Agric. Water Management, 26, 67-80

Rao, V.N., Rego, T.J. and Meyer, R.J.K. (1997). Balanced fertilizer use in black soils. Fertilizer News, 42(2), 35-5.

Reddy, R.S. (2006). Methodology for correlation of soil series in soil survey and mapping. Agropedology, 16, 111

Richards, E.A. (1954). Diagnosis and improvement of saline and alkaline soils. Agriculture Hand book No.60. United States Salinity Laboratory, USDA.

Sanchez, P.A., Palm, C.A. and Boul, S.W. (2003). Fertility capability soil classification: a tool to help assess soil quality in the tropics. Geoderma, 114, 157-85

Schafer, W.M. and Singer, M.J. (1976). A new method of measuring shrink-swell potential using soil paste. Soil Sci. Soc. Amer. J., 40, 805-6

Schoeneberger, P J., Wysocki, D.A., Benham, E.C., and Borderson, W.D. (2002). Field book-Describing and Sampling Soils. version 2.NRSC, National Soil Survey Centre, Lincoln, NE.

Soil Survey Staff (2014). Keys to Soil Taxonomy. $12^{\text {th }}$ edition. USDA/NRSC, Washington, DC.

Sys, C., Van Ranst, E., and Debaveye, J. (1991). Land evaluation, Part II. Methods in land evaluation. General administration for development cooperation, Brussels, pp: 247

Sys, C., van Ranst, E. and Debaveye, J. (1993). Land Evaluations, Part IIII: Principles in landevaluation and crop production calculation. General Administration for Development Cooperation, Brussels. 